cover that there were no legal requirements that the funds be used for library acquisition. As a result, by the time I left Bridgewater State in 1973, more than half of the Library Development Trust Fund annually was being used to pay the salary of part-time staff members and some full-time staff members.-Tom Watson, University Librarian, University of the South, Sewanee, Tennessee.

Editor's Note: Massachusetts state college libraries still assess this fee, which can be used in many different ways. Massachusetts state community college libraries do not have this fee.

\title{
ACRL Chapters
}

- The California ACademic and Research Librarians (CARL), ACRL's California Chapter, will hold a Northern California program on grants for academic and research librarians. It will be held at California State University, Hayward, on March 20 from 9:30 to 3:30 p.m. The program will provide a forum for exchanging ideas and information with librarians who are interested in grants. The program moderator will be Michael Bruer, associate director, California Library Authority for Systems and Services. The fee will be $\$ 12$ for CARL members, $\$ 14$ for California Library Association or ACRL members wishing to join CARL, and $\$ 15$ for non-CARL members. For further information, contact Jo Bell Whitlatch, Access Coordinator, San Jose State University Library, San Jose, CA 95152 . Deadline for registration is March 11.

- The Iowa Chapter will hold a spring workshop in April, hosted jointly by Marycrest and St. Ambrose Colleges in Davenport. The workshop (tentatively scheduled for April 10 or 24) will be titled "Libraries in an Electronic Society." For more information, contact: Corinne Potter, St. Ambrose College, $518 \mathrm{~W}$. Locust St., Davenport, IA 52803.

- The Missouri Association of College and RESEARCH LIBRARIES spring workshop will focus on "What Everyone Should Know About Grant Writing." To be held in Springfield on April 4, the day will consist of a brief business meeting, presentations, lunch, continuation of presentations, and a tour of the new library at Southwest Missouri State University in Springfield. Although the registration fee is not finalized, a tentative cost of $\$ 10-\$ 20$, lunch included, has been reported. For further information, contact: Joyce Ann Jaillite, Reference Department, PML, Northeast Missouri State University, Kirksville, MO 63501; (816) 665-5121, Ext. 2749.

- The Nebraska Library Association's College and University Section/ACRL Chapter has scheduled its spring meeting for Friday, April 24. The topic has not yet been announced. For more information, contact: Karen Kozak, Head of Cataloging, Creighton University, Alumni Library, 2500 California St., Omaha, NE 68178.

- The New England Chapter will hold its spring meeting at Mount Holyoke College, South Hadley, Massachusetts, on March 26-27. The program is entitled "Academic Libraries in the Changing World of Higher Education," and one of the themes will focus on continuing education. For more information, contact: John Hannon, Director of Library Services, Bryant College, Smithfield, RI 02917; (401) 231-1200, Ext. 300.

- The Oregon Chapter held a joint meeting with the Oregon Community College Library Association on February 20 at Linn-Benton Community College Library in Albany. The topic of the meeting was the state librarian's Automation Study Committee report which recommended guidelines for developing automation for resource sharing in Oregon.

The chapter will hold its spring meeting in Ashland, Oregon, on April 25 in conjunction with a meeting of the Academic Section of the Oregon Library Association. For further details about either of these meetings, contact: Virginia Seiser, Assistant Education Librarian, Portland State University, P.O. Box 1151, Portland, OR 97207.

- The Texas Chapter will present "Online Library Catalogs: A Preconference to the Annual Conference of the Texas Library Association" on March 31 at the Albert Thomas Convention Center in Houston. The program will consist of a series of presentations by librarians involved with online catalogs, with questions and answers after each. The preconference, which costs $\$ 15$ for preregistrants or $\$ 20$ at the door, features sessions titled: Requirements for Online Catalogs; Hardware and Software to Support Online Library Catalogs; Planning, Creating, and Maintaining the Bibliographic Data Base; Selling and Explaining the Online Catalog to a User Community; and Costs of Online Library Catalogs. A separate business meeting will be held Thursday, April 2 . For further information, contact: Vandolyn Savage, $5550 \mathrm{~N}$. Braeswood, \#78, Houston, TX 77096 .

- The Wisconsin association of ACademic Librarians/ACRL Chapter will hold a program meeting April 29-May 1 at Nicolet College in Rhinelander, on "Academic Library Management and Bibliographic Instruction." There will be three general sessions and one afternoon of small group sessions relating to each topic. Contact: Tamara Miller, Wisconsin Library Consortium, Room 464, Memorial Library, Madison, WI 53706 . 